\title{
Organisational Effectiveness in a Metropolitan Municipality: Proposing and Validating a Model
}

\author{
Benny Olivier \\ University of South Africa \\ Department of Industrial and \\ Organisational Psychology \\ olivibh@unisa.ac.za
}

\author{
Nico Martins \\ University of South Africa \\ Department of Industrial and \\ Organisational Psychology
}

\begin{abstract}
This study aims to propose and validate a model of organisational effectiveness which could be utilised by a metropolitan municipality to address problems and weaknesses in order to maintain its credibility in the eyes of the public and fulfil its legislatively prescribed mandate. As a first step, this study designed a conceptual model of organisational effectiveness for a metropolitan municipality by including organisational and behavioural variables published in previous studies, as well as variables contained in existing models of effectiveness. To validate the model, the next step was to conduct a crosssectional survey using the Effectiveness Survey (ES) in an existing metropolitan municipality in South Africa $(n=6514)$ and expose the data gathered to structural equation modelling (SEM). The confirmatory factor analysis that was conducted subsequently confirmed the existence of the three main variables proposed in the conceptual model, namely Healthy Systems, Goal Achievement and Service Delivery, but did not support all the hypothesised relationships between these variables. The implications of the statistically significant and insignificant relationships obtained are discussed and the utility of SEM as a means of validating a conceptual model is confirmed.
\end{abstract}

Keywords: organisational effectiveness; metropolitan municipality; structural equation modelling; local government

\section{Introduction and Background}

Metropolitan municipalities are classified as local governments and part of the public sector in South Africa. As such, they are generally viewed as engines of economic

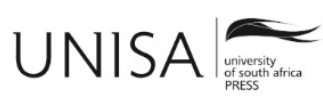


growth, have a high population density and have multiple overlapping externalities (Reddy, 2008). South Africa has eight metropolitan municipalities with over 20 million inhabitants, which is $38 \%$ of the total population of South Africa (Statistics South Africa [Stats SA], 2013). According to Atkinson (2007) and Leibbrandt and Botha (2014), the majority of local governments in South Africa are underperforming, are deemed to be ineffective and are in crisis when it comes to their constitutional responsibilities.

According to Waheed, Mansor, and Ismael (2010), it has become imperative for public sector organisations to assess their performance in relation to their legislatively prescribed mandate and take the necessary steps to address problems and weaknesses in order to maintain their credibility in the eyes of the public. These authors argue that the ability to define and evaluate performance is an essential condition for its improvement. Soni (2011) goes further by stating that improving the performance of public sector organisations is a major concern for public officials, administrators, and citizens in all democratic societies today.

\section{Literature Review}

\section{Measuring Public Sector Organisational Effectiveness}

Although there is no consensus regarding theories of organisational effectiveness (Cameron, 1986; Connolly, Conlon, \& Deutsch, 1980; Hrebiniak, 1978; Rojas, 2000; Steers, 1977), various approaches to dealing with the need have evolved over the past 58 years. The Criteria approach (Harrison, 2005; Steers, 1977; Thorndike, 1949; Yuchtman \& Seashore, 1967), for example, focuses on various univariate and multivariate criteria for measuring organisational effectiveness, while the Goal approach (Brown, 2011; Cameron, 1986; Price, 1972) uses the accomplishment of organisational goals to determine organisational effectiveness. The Systems Resource approach (Glunk \& Wilderom, 1999; Price, 1972; Yuchtman \& Seashore, 1967) uses the ability of an organisation to obtain resources from its environment as the measure of organisational effectiveness, and the Internal Processes (Healthy Systems) approach (Beulens, Sinding, Waldstrom, Kreitner, \& Kinicki, 2011; Daft, 1992; Wiley, 2010) uses the degree of harmonious balance between various internal structural features as the measure of organisational effectiveness. Lastly, the Strategic Contingencies approach (Cameron \& Whetten, 1983; Martz, 2008; Tsui, 1984) uses the satisfaction of key stakeholders as the ultimate measure of organisational effectiveness.

Regarding the measurement of public sector and local government performance, Gawande and Wheeler (1999) and Poister and Streib (1999) state that an organisation whose actions are regulated by government and whose objectives are not necessarily measurable in terms of financial qualities poses a challenge. There are two reasons for this: firstly, governments tend to change priorities to adapt to the needs of a variety of stakeholders, and secondly, the provision of services is more difficult to measure than financial objectives. This view is supported by Van Thiel and Leeuw (2002), who state that performance assessment systems should take the special characteristics of the 
public sector into account, such as mandates which are determined by legislation, service delivery as an important output and the fact that financial profit is not the basis for the existence of public sector organisations, as it is for the private sector. For this reason, Parhizgari and Gilbert (2004) state that the key features of effective performance in the private sector cannot be applied to the public sector, as the two sectors are structured differently, and it is therefore reasonable to assume that organisational effectiveness measures in public and private organisations may be quantitatively different.

It is clear from the above discussion that various authors support the view that it is more difficult to measure organisational performance in the public sector, which includes local government, than in the private sector (Boyne \& Chen, 2006; Stevens, 2005; Vaughan, 2010; Waheed, Mansor, \& Ismael, 2010).

\section{Existing Models for Measuring Organisational Effectiveness}

According to Brown (2011), Cummings and Worley (2015) and Harrison (2005), the existing assessment models can be grouped into three levels: namely the individual level, the group level and the organisational level. The first two categories focus on the individual and group levels of organisational functioning, but the latter category focuses on the functioning of the entire organisation. Although many frameworks and models exist for assessing the total functioning of private and public-sector organisations (Cummings \& Worley, 2015; French \& Bell, 1978; Martins \& Geldenhuys, 2016), not all organisation-level models assess the organisational effectiveness (emphasis added) of an organisation.

Table 1 below shows eight existing assessment models that can be used to assess the organisational effectiveness of an organisation. Although all eight of these assessment models have been used successfully in a variety of different situations, none has been specifically developed to assess the total organisational effectiveness of a metropolitan municipality in South Africa. A new conceptual model has therefore been proposed for this purpose. 
Table 1: Assessment models which assess the organisational effectiveness of a total organisation

\begin{tabular}{|l|l|}
\multicolumn{1}{|l|}{ Name of model } & Reference(s) \\
\hline Weisbord's Six-Box Model & Weisbord (1976) \\
\hline $\begin{array}{l}\text { The Nadler-Tushman Congruence Model for } \\
\text { Organizational Analysis }\end{array}$ & $\begin{array}{l}\text { Waterman, Peters, and } \\
\text { Phillips (1980); Higgins } \\
(2005)\end{array}$ \\
\hline The 7-S/8-S Framework & Tichy (1983) \\
\hline $\begin{array}{l}\text { Tichy's Technical Political Cultural (TPC) } \\
\text { Framework }\end{array}$ & Burke and Litwin (1992) \\
\hline The Causal Model of Organizational Performance & Kaplan and Norton (1992) \\
\hline The Balanced Scorecard & Nel and Haycock (2005) \\
\hline $\begin{array}{l}\text { The South African Excellence Model for Local } \\
\text { Government (adapted from the South African } \\
\text { Excellence Model to make it applicable to local } \\
\text { governments) }\end{array}$ & \\
\hline The High Performance Model & Wiley (2010) \\
\hline
\end{tabular}

\section{Proposed Conceptual Model of Organisational Effectiveness}

On the basis of the above literature review, a new conceptual model of organisational effectiveness for a metropolitan municipality in South Africa is proposed, consisting of three main variables: Healthy Systems (the degree of harmonious balance between various internal structural features), Goal Achievement and Service Delivery, and nine secondary organisational and behavioural variables.

\section{Healthy Systems}

Beulens et al. (2011, p. 486) use the words "healthy systems" to refer to an organisation that functions smoothly with a minimum of internal strain. That is, information flows smoothly, employees are loyal and committed, and job satisfaction and trust prevail. It also means a harmonious balance of structural features and an organisational type with a good fit. In this study, healthy systems as a dimension of organisational effectiveness are conceptualised as including seven elements, namely (1) internal functioning (the variety and effectiveness of processes taking place in an organisation, such as communications, procedures and changes for improvement); (2) management practices (what managers and leaders do with the human and material resources at their disposal); (3) teamwork (the degree of cooperation between employees); (4) work environment (the availability of required resources for employees to do their work); (5) rewards and recognition (the compensation of employees for work delivered); (6) training and development (the systematic effort by organisations to facilitate the learning of jobrelated knowledge and behaviours); and (7) interpersonal relations (how people relate to each other in the workplace). 


\section{Goal Achievement}

Beulens et al. (2011) state that goal accomplishment is the most widely used effectiveness criterion for organisations, despite the wide variations found in different organisational mandates, circumstances and contexts, all of which influence the perception of what goal achievement is. In this respect, Cameron (1986), Glunk and Wilderom (1999), Martz (2008) and Price (1972) state that the greater the degree to which an organisation achieves its goals, the greater its effectiveness. In this study, goal achievement as a dimension of organisational effectiveness is conceptualised as the achievement of the vision and mission of an organisation.

\section{Service Delivery}

Customer satisfaction and effective service delivery are often used to refer to the same concept (Immordino, 2010; Nel \& Haycock, 2005; Wiley, 2010). Immordino (2010) states that customer satisfaction in a government institution has to do with the identification of needs, expectations, perspectives and satisfaction level of its constituencies, namely the individuals, groups, the public, organisations and all other stakeholders for which it provides programmes or services. Research has shown that customer and stakeholder satisfaction leads to goal achievement, performance excellence and positive organisational results (Baldrige National Quality Program, 2007; Immordino, 2010; Nel \& Haycock, 2005; Wiley, 2010). In this study, service delivery as a dimension of organisational effectiveness is conceptualised as including customer satisfaction.

The proposed new conceptual model is illustrated in Figure 1 below. It suggests that if a metropolitan municipality has healthy systems (the degree of harmonious balance between various internal structural features), this will facilitate the achievement of its goals as stipulated in its vision and mission and will ensure effective and efficient service delivery. Furthermore, if a metropolitan municipality delivers the services that it should, thereby ensuring customer satisfaction, this will positively affect the achievement of its goals as stipulated in its vision and mission, while if it achieves its goals as stipulated in its vision and mission, this will positively affect the delivery of the expected services, thereby ensuring customer satisfaction.

The research hypotheses are the following:

$\mathrm{H}_{1}$ : $\quad$ There is a significant statistical relationship between Healthy Systems and Goal Achievement.

$\mathrm{H}_{2}$ : There is a significant statistical relationship between Healthy Systems and Service Delivery.

$\mathrm{H}_{3}$ : There is a significant statistical relationship between Goal Achievement and Service Delivery. 
$\mathrm{H}_{4}$ : There is a significant statistical relationship between Service Delivery and Goal Achievement.

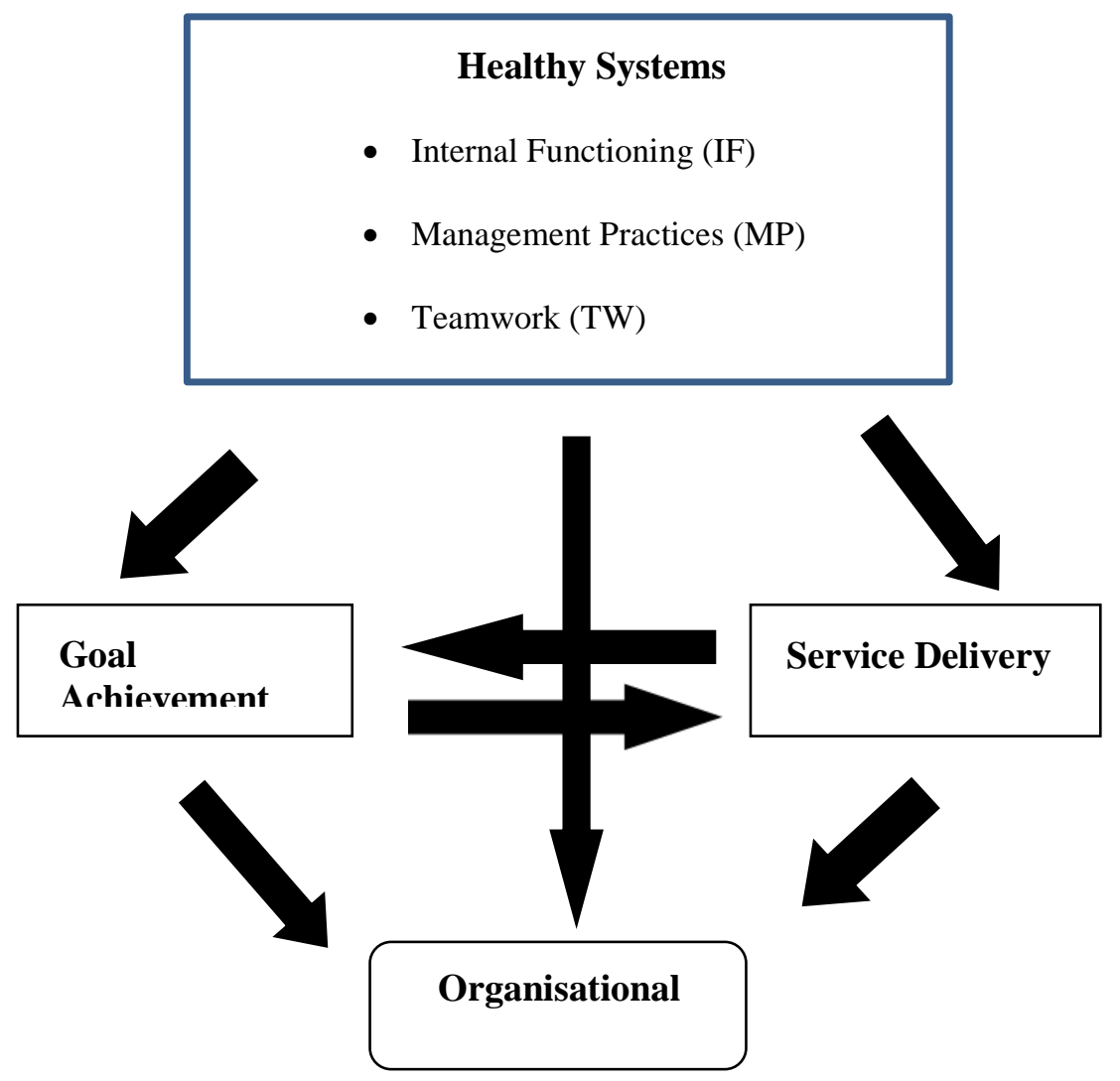

Figure 1: Conceptual model of organisational effectiveness for a metropolitan municipality in South Africa (Source: Olivier \& Martins, in press)

\section{Validating the Proposed Conceptual Model}

\section{Research Methodology}

A quantitative, cross-sectional survey strategy of inquiry was used, and primary data were collected by means of a predetermined instrument in order to obtain statistical data to validate the proposed conceptual model (Babbie, 2010; Creswell, 2009).

\section{Research Participants}

The population for this study comprised all the employees of one of the largest of the eight metropolitan municipalities in South Africa ( $\mathrm{n}=16006$ members). The convenience sampling method, a nonprobability sampling method (Babbie, 2010), was used for this study. All employees in the population were invited to voluntarily complete 
the survey instrument. A total of 6715 responses were received, yielding a sample of 42\%. According to Babbie (2010), Curry and Gay (1987), Martinez-Pons (1997) and Wiley (2010), a sample size of $40 \%$ or more is an adequate representation of the population for survey purposes.

The majority of the sample were female (62\%) and over the age of 25 years (96\%), which means that very few young employees took part in the survey. Regarding race, the majority of the sample consisted of black Africans (82\%), which is in line with the demographic composition of South Africa (Stats SA, 2013).

\section{The Measuring Instrument}

The Effectiveness Survey (ES) developed by Martins and Coetzee (2007) was used to gather the required data to validate the proposed conceptual model. The ES is a selfevaluation survey questionnaire that can be administered electronically or on hard copy to individuals or groups. Martins and Coetzee (2007) state that the ES was developed specifically for a South African organisation on the basis of intensive interviews and focus group input. The questionnaire consisted of two sections, namely Biographical Information and Survey Statements. A total of 78 statements were used to measure 13 dimensions of organisational effectiveness.

The researchers decided to use an ES to gather the required data to validate the proposed conceptual model because, according to Martins and Coetzee (2007), it is reliable (overall Cronbach's alpha of 0.88 and internal consistency among dimensions ranging between 0.86 and 0.92), valid (content validity was established by the authors), affordable and easy to administer, and furthermore the ES covered most of the hypothesised variables in the proposed conceptual model. Respondents were required to rate each of the 78 statements on a 5-point Likert scale (Likert, 1932).

\section{Research Procedure}

Permission to gather the research data was obtained from the relevant authority in the metropolitan municipality and ethical clearance to conduct the study was obtained from the University of South Africa's Ethics Committee. A pilot study was conducted with a draft version of the questionnaire so that it could be customised if necessary. A group of human resource managers representing the different departments and business units and union representatives in the metropolitan municipality were requested to complete the questionnaire. The purpose of this pilot study was to test the questionnaire's content validity, and accordingly respondents were requested to check three aspects:

- Was the terminology used appropriate for the metropolitan municipality?

- $\quad$ Did they understand the questions posed?

- $\quad$ Did the questions cover all relevant issues in the metropolitan municipality?

- Was the correct biographical information requested from respondents? 
The inputs from this pilot study were used to adapt the draft questionnaire (Martins \& Coetzee, 2007), and this adapted questionnaire was then used to gather data from the members of the municipality. The questionnaire was completed online by participants who had access to the internet, or on hard copy by those who did not.

\section{Statistical Analysis}

All the data gathered were analysed using the IBM Statistical Package for the Social Sciences (SPSS) Version 23 (IBM, 2015). The data obtained from the self-reporting survey instrument were used to produce descriptive statistics to describe the sample (Church \& Waclawski, 1998), conduct an item analysis to test the reliability of the measurement instrument (Babbie, 2010), conduct an exploratory factor analysis to identify the underlying relationships between the measured variables, and validate the proposed conceptual model by means of structural equation modelling (Hair, Black, Babin, \& Anderson, 2010).

Kline (2011) proposed a two-step model-building approach to structural equation modelling (SEM), namely to firstly develop a measurement model and test its validity, and then develop a structural model and test its validity. The following six goodnessof-fit (GOF) indices were used to validate the measurement and structural models:

- Chi-square (CMIN). According to Hoe (2008), values closer to zero, indicating non-significance, would indicate a good fit.

- Goodness-of-Fit Index (GFI). The GFI ranges between 0 and 1, with a cut-off value of 0.9 generally indicating acceptable model fit (Baumgartner \& Homburg, 1996; Kline, 2011).

- Root Mean Square Error of Approximation (RMSEA). According to Hu and Bentler (1999) and Kline (2011), the RMSEA ranges from 0 to 1, with lower values indicating better model fit, and a value of 0.06 or less being indicative of acceptable model fit.

- Normed Fit Index (NFI). According to Hu and Bentler (1999), values for the NFI should range between 0 and 1, while Hair et al. (2010) recommend a level of 0.90 or above as indicating a good model fit.

- Tucker-Lewis Index (TLI). Hair et al. (2010) recommend a level of 0.90 or above as indicating a good model fit.

- Comparative Fit Index (CFI). According to Hu and Bentler (1999) and Hoe (2008), CFI values range from 0 to 1 , with higher values indicating better fit, while a value of 0.90 or above is generally considered to indicate acceptable model fit. 


\section{Results}

\section{Descriptive Statistics: Effectiveness Survey Dimensions}

Table 2 below shows the mean and standard deviation for each of the 13 dimensions of the ES and indicates that the sample size for respondents was 6514 after listwise deletion for missing data. According to Roth (1994), listwise deletion is the preferable method for handling missing data, and the researchers opine that the missing data had no effect on the statistical power of the analyses conducted (Peng, Harwell, Liou, \& Ehman, 2006).

For the purposes of this study, the recommended mean cut-off score of 3.2 on a scale of 1-5 was used to differentiate between potential positive and negative responses, with scores above 3.2 indicating a positive perception and scores below 3.2 indicating a negative perception of that dimension. Research indicates that an average of 3.2 is a good guideline for distinguishing between positive and potential negative perceptions (Castro \& Martins, 2010; Ledimo, 2012).

Table 2: Means and standard deviations for the 13 dimensions of the ES (Average $\mathrm{n}=$ 6514 after listwise deletion for missing data)

\begin{tabular}{|ll|l|l|}
\hline \multicolumn{2}{|l|}{ ES dimension } & Mean & Standard deviation \\
\hline $1 . \quad$ Vision and Mission & 3.66 & 1.30 \\
\hline $2 . \quad$ Values & 3.96 & 1.11 \\
\hline $3 . \quad$ Diversity & 3.18 & 1.36 \\
\hline $4 . \quad$ Employee Relations & 2.86 & 1.39 \\
\hline $5 . \quad$ Teamwork & 3.46 & 1.33 \\
\hline $6 . \quad$ Management & 3.20 & 1.37 \\
\hline $7 . \quad$ Trust & 3.27 & 1.30 \\
\hline $8 . \quad$ Communication & 3.08 & 1.38 \\
\hline $9 . \quad$ Training and Development & 3.06 & 1.05 \\
\hline $10 . \quad$ Work Environment & 3.26 & 1.40 \\
\hline $11 . \quad$ Rewards and Recognition & 2.55 & 1.31 \\
\hline 12. & Change Management & 2.87 & 1.33 \\
\hline $13 . \quad$ Employee Engagement & 3.34 & 1.33 \\
\hline TOTAL for the ES & $\mathbf{3 . 2 1}$ & $\mathbf{1 . 3 0}$ \\
\hline
\end{tabular}

Source: Survey data

\section{Reliability of the Measurement Instrument}

Using the 13 pre-determined dimensions of the ES, an item analysis was conducted to determine the internal consistency of the measurement instrument, defined as the degree to which responses are consistent across the items within a measure (Green \& Salkind, 2014). All the dimensions demonstrate high internal consistency, ranging from a low of 
0.79 to a high of 0.95 , with an overall reliability of 0.86 which, according to Hair et al. (2010), is deemed acceptable for research purposes.

\section{Exploratory Factor Analysis}

An exploratory factor analysis (EFA) was conducted to identify the underlying relationships between the measured variables to identify a set of latent variables (Fabrigar, Wegener, MacCallum, \& Strahan, 1999). In order to do this, the questions of the ES that measured respondents' perceptions regarding the organisational effectiveness of their metropolitan municipality were subjected to a principal component analysis (PCA) (Kline, 2011).

Prior to performing PCA, the suitability of the data for factor analysis was assessed. To do this, the relationships among the 78 variables that were measured were investigated using Pearson's Product-Moment Correlation Coefficient (Babbie, 2010). The resultant correlation matrix confirmed the presence of a number of coefficients of 0.3 and above. In addition, the Kaiser-Meyer-Olkin value was 0.982, exceeding the recommended minimum value of 0.6 suggested by Kaiser (1974). The Bartlett's Test of Sphericity (Bartlett, 1954) also reached statistical significance at the $\mathrm{p}<0.001$ level, supporting the factorability of the correlation matrix.

The researchers' next step was to select the appropriate number of factors to include in the model. For this study, the researchers decided to use one of the most common and widely used procedures for determining which factors to retain (Fabrigar et al., 1999; Hair et al., 2010; Ruscio \& Roche, 2012), namely Kaiser's (1974) eigenvalue-greaterthan-one rule (or $\mathrm{K} 1$ rule).

PCA, using the 78 original items, revealed the presence of 12 factors with eigenvalues exceeding 1 but the solution was not acceptable. Allowing the solution to consider only 11 factors resulted in a more interpretable solution. Two of the items (questions) were excluded in the final analysis because they did not load sufficiently on any of the components and their deletion resulted in the solution's explaining more variance in the data.

Table 3 below confirms that PCA using the remaining 76 items revealed the presence of only 11 components with eigenvalues exceeding 1, cumulatively explaining 63.35\% of the variance in the data. The next highest eigenvalue obtained was 0.958, substantially below the 11th cut-off point of 1.92 . 
Table 3: Total variance explained by 11 components obtained from the exploratory factor analysis with the remaining 76 items

\begin{tabular}{|l|l|l|l|}
\hline \multirow{2}{*}{ Component } & \multicolumn{3}{|l|}{ Rotation sums of squared loadings } \\
\cline { 2 - 4 } & Eigenvalues & \% of variance & Cumulative \% \\
\hline 1 & 12.53 & 16.49 & 16.49 \\
\hline 2 & 9.10 & 11.98 & 28.47 \\
\hline 3 & 5.32 & 7.01 & 35.47 \\
\hline 4 & 4.78 & 6.29 & 41.76 \\
\hline 5 & 3.11 & 4.09 & 45.85 \\
\hline 6 & 2.47 & 3.25 & 49.09 \\
\hline 7 & 2.41 & 3.17 & 52.27 \\
\hline 8 & 2.36 & 3.11 & 55.37 \\
\hline 9 & 2.22 & 2.93 & 58.30 \\
\hline 10 & 1.92 & 2.52 & 60.82 \\
\hline 11 & 1.92 & 2.52 & 63.35 \\
\hline
\end{tabular}

Source: Survey data

The Varimax orthogonal rotation method - the most widely used, simplest and conceptually clearest method-was used (Fabrigar et al., 1999). The rotated solution revealed the presence of a simple structure (Thurstone, 1947) of 11 components showing a number of significant loadings, with loadings of less than 0.4 being excluded from the solution according to the guidelines provided by Hair et al. (2010). In order to label the 11 identified factors, the factor pattern and factor loadings were studied to determine what the items had in common (Fabrigar et al., 1999). The researchers also revisited the secondary organisational and behavioural variables of organisational effectiveness that were included in the proposed conceptual model for measuring the organisational effectiveness of a metropolitan municipality in South Africa in the first step of this study. In addition, the original 13 dimension names used in the ES were also considered. After taking all the above into account, it was decided to name the 11 components as follows:

- Component 1: Management Practices (MP). A typical question under this component reads as follows: "My immediate supervisor/manager gives me clear instructions."

- Component 2: Internal Functioning (IF). A typical question under this component reads as follows: "We have regular staff meetings in my department."

- Component 3: Customer Satisfaction (CS). A typical question under this component reads as follows: "My organisation is focused on ensuring that our customers are satisfied with our services." 
- Component 4: Diversity (D). A typical question under this component reads as follows: "In my team/function all races are represented."

- Component 5: Training and Development (T and D). A typical question under this component reads as follows: "I have received the training I need to do my job.”

- Component 6: Vision and Mission (V and M). A typical question under this component reads as follows: "I am aware of my organisation's vision and mission.”

- Component 7: Rewards and Recognition (R and R). A typical question under this component reads as follows: "My immediate supervisor/manager recognises and/or compliments me for work well done.”

- Component 8: Work Environment (WE). A typical question under this component reads as follows: "The conditions at the place where I normally work allow me to do my best work."

- Component 9: Interpersonal Relations (IR). A typical question under this component reads as follows: "My organisation treats its employees with dignity and respect.”

- Component 10: Teamwork (T). A typical question under this component reads as follows: "In my department we work together as a team."

- Component 11: Workforce Equality (WEq). A typical question under this component reads as follows: "Racism seldom occurs in my organisation."

The next step required to validate the proposed conceptual model of organisational effectiveness was to conduct a confirmatory factor analysis, using the 11 factors identified as part of the SEM process, in order to develop and specify measurement and structural models (Kline, 2011).

\section{Structured Equation Modelling}

\section{Assessing First-Order Measurement Model Validity}

A confirmatory factor analysis (CFA) was conducted in order to develop and specify the measurement model (Hair et al., 2010) on the first-order construct level. Analysis of Moment Structures (AMOS), a module of the IBM SPSS Version 23 (IBM, 2015), was used to conduct the CFA. The CFA was conducted using the 11 factors (components) identified during the EFA.

One construct, namely Component 10 (Teamwork), was removed from the model, as the two variables that loaded on it had a low squared multiple correlation (SMC). The standardised regression weights of the remaining 10 variables were all significant, making model trimming unnecessary. 
Once the first-order measurement model had been specified, its validity had to be determined, which depended on establishing acceptable levels of goodness-of-fit (GOF). According to Hair et al. (2010), GOF indicates how well the specified model reproduces the observed covariance matrix among the indicator items. The GOF indices obtained for the first-order measurement model and the interpretation are given in Table 4 below.

Except for the chi-square index, all the other GOF indices were at a level recommended by various authors (Hair et al., 2010; Hu \& Bentler, 1999). The researchers therefore accepted the obtained measurement model as valid for the first-order constructs.

Table 4: Goodness-of-fit indices for the first-order measurement model

\begin{tabular}{|c|c|c|}
\hline Indices & Value & Interpretation \\
\hline \multicolumn{3}{|l|}{ Absolute Fit Indices } \\
\hline $\begin{array}{l}\text { Chi-square (CMIN) } \\
\text { Chi-square degrees of freedom } \\
\text { (d) } \\
\text { P-value }\end{array}$ & $\begin{array}{l}17379.133 \\
1763 \\
0.000\end{array}$ & $\begin{array}{l}\text { Not a good model fit based on } \\
\text { CMIN value. However, the size } \\
\text { of the sample (average } n=6514 \\
\text { after listwise deletion) reduces } \\
\text { the meaningfulness of this GOF } \\
\text { index (Gatignon, 2010). For this } \\
\text { reason, many authors disregard } \\
\text { the chi-square index for samples } \\
\text { larger than } 200 \text {. }\end{array}$ \\
\hline Goodness-of-Fit Index (GFI) & 0.914 & A good model fit \\
\hline $\begin{array}{l}\text { Root Mean Square Error of } \\
\text { Approximation (RMSEA) }\end{array}$ & 0.036 & A good model fit \\
\hline \multicolumn{3}{|l|}{ Incremental Fit Indices } \\
\hline Normed Fit Index (NFI) & 0.937 & A good model fit \\
\hline Tucker-Lewis Index (TLI) & 0.939 & A good model fit \\
\hline Comparative Fit Index (CFI) & 0.943 & A good model fit \\
\hline
\end{tabular}

Source: Survey data

\section{Developing and Specifying the Second-Order Measurement Model}

The first-order factor model specified and validated above means that the covariances between measured items (the items on the ES) are explained by a single-factor layer (the final 10 constructs). The researchers employed higher-order factor analysis to test a second-order factor structure that contains two layers of constructs (Hair et al., 2010). This was done by introducing three second-order latent factors that were hypothesised as causing the 10 first-order observed or manifested factors, which in turn cause the measured variables (items on the ES). According to Hair et al. (2010), the 10 first-order manifested factors now act as indicators of the three second-order latent factors. The three second-order latent constructs that were hypothesised as causing the 10 first-order 
manifested factors are depicted in Figure 2 below with their standard regression weights. As can be seen from Figure 2, all estimates were significant, indicating that the secondorder latent variables explain significant proportions of variance in the first-order manifested variables (Patterson et al., 2005).

Assessing Second-Order Measurement Model Validity

Once the second-order measurement model had been specified, its validity also needed to be determined, as Hair et al. (2010) state that higher-order models are subject to the same validity standards as first-order models. The same GOF guidelines used for the first-order measurement model were used for the second-order measurement model as well. The GOF indices obtained and interpretations for the second-order measurement model are given in Table 5 below. 


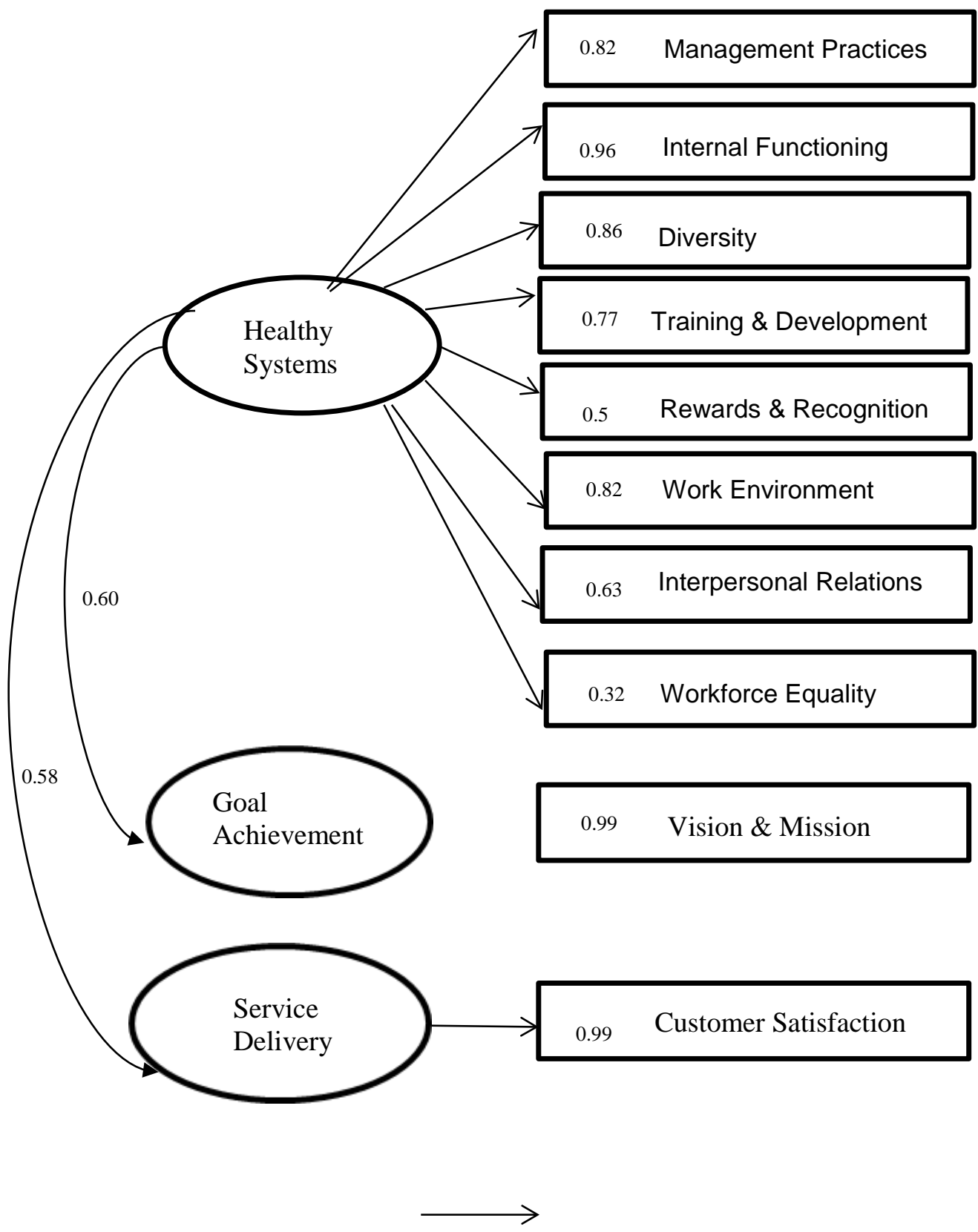

Figure 2: The specified second-order measurement model (Source: Survey data) 
Table 5: Goodness-of-fit indices for the second-order measurement model

\begin{tabular}{|l|l|l|}
\hline Indices & Value & Interpretation \\
\hline Absolute Fit Indices & & \\
\hline $\begin{array}{l}\text { CMIN } \\
\text { Chi-square degrees of freedom } \\
\text { (d) } \\
\text { P-value }\end{array}$ & $\begin{array}{l}19633.78 \\
1797 \\
0.000\end{array}$ & $\begin{array}{l}\text { Disregarded due to the large } \\
\text { sample size }\end{array}$ \\
\hline Goodness-of-Fit Index (GFI) & 0.901 & A good model fit \\
\hline $\begin{array}{l}\text { Root Mean Square Error of } \\
\text { Approximation (RMSEA) }\end{array}$ & 0.038 & A good model fit \\
\hline Incremental Fit Indices & & \\
\hline Normed Fit Index (NFI) & 0.929 & A good model fit \\
\hline Tucker-Lewis Index (TLI) & 0.932 & A good model fit \\
\hline Comparative Fit Index (CFI) & 0.935 & A good model fit \\
\hline
\end{tabular}

Source: Survey data

Except for the chi-square index, all the other GOF indices were at a level recommended by various authors (Hair et al., 2010; Hu \& Bentler, 1999). The researchers therefore accepted the measurement model obtained as being valid for the second-order latent constructs.

\section{Specifying the Structural Model}

According to Kline (2011), the next step in the SEM process is to specify the structural model. The structural model depicted in Figure 3 below was specified by hypothesising relationships among the second-order latent constructs, and these hypothesised relationships were based on the conceptual model proposed in step 1 of this study. These hypothesised structural relationships are depicted by single-headed, directional arrows showing the dependence relationships in Figure 3 below. To assess the acceptability of the hypothesised structural model, the regression weights obtained between the secondorder latent constructs from the CFA for the structural model were considered. These are depicted in Figure 3 below as well. 


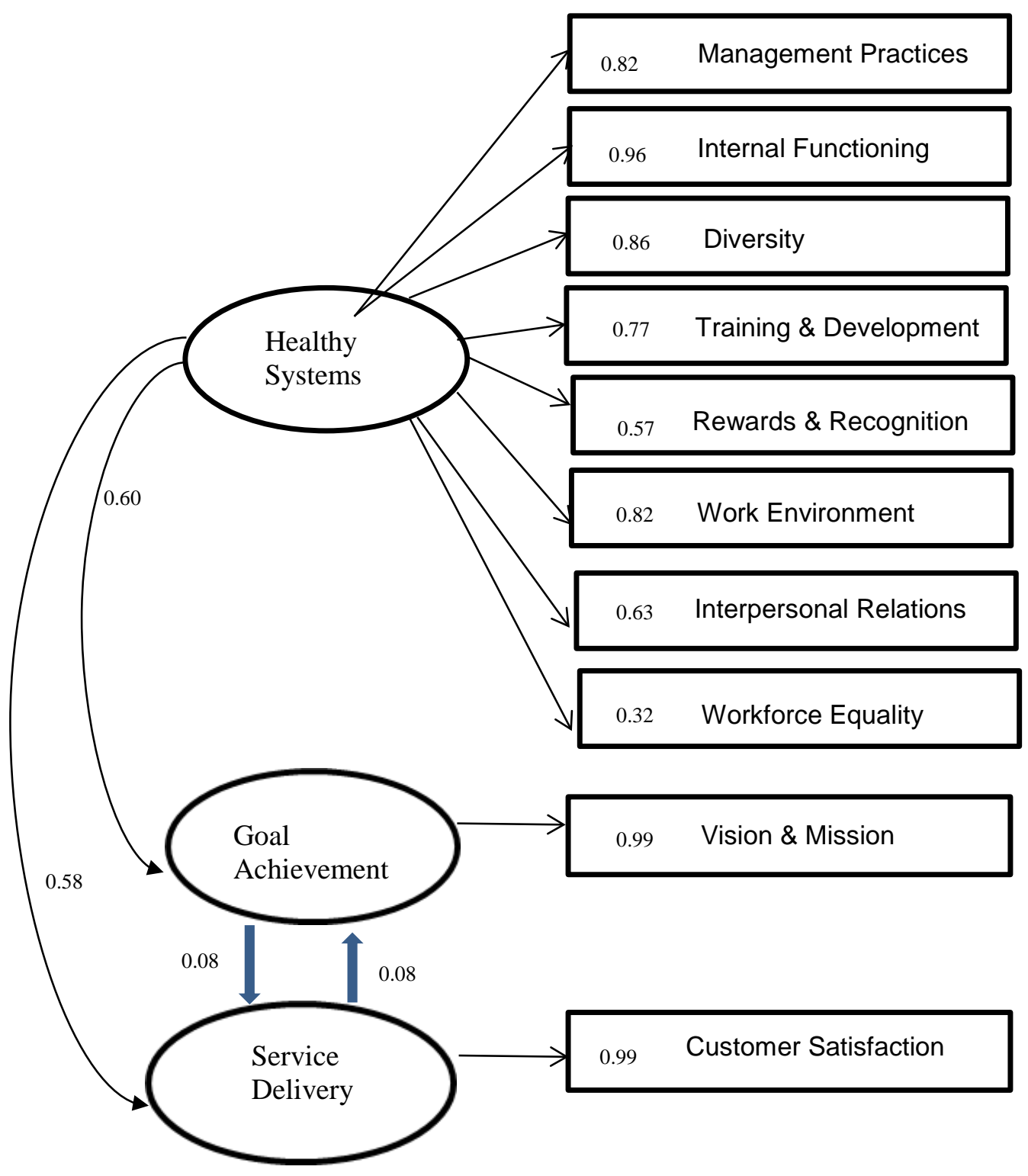

Figure 3: The specified, hypothesised structural model and the subsequent regression weights obtained (Source: Survey data)

The regression weight estimates indicated that there is a statistically significant relationship between Healthy Systems and Service Delivery (0.58), and Healthy Systems and Goal Achievement (0.60), but there is an insignificant statistical relationship between Service Delivery and Goal Achievement (0.08) and between Goal Achievement and Service Delivery (0.08). 
Assessing the Structural Model Validity

Table 6 below indicates the GOF indices that were obtained for the structural model, which are mostly the same as the GOF indices obtained for the second-order measurement model (see Table 5 above).

Table 6: Goodness-of-Fit indices for the structural model

\begin{tabular}{|c|c|c|}
\hline Indices & Value & Interpretation \\
\hline \multicolumn{3}{|l|}{ Absolute Fit Indices } \\
\hline $\begin{array}{l}\text { Chi-square (CMIN) } \\
\text { Chi-square degrees of } \\
\text { freedom (d) } \\
\text { P-value }\end{array}$ & $\begin{array}{l}19661.858 \\
1798 \\
0.000\end{array}$ & $\begin{array}{l}\text { Disregarded due to the large } \\
\text { sample size }\end{array}$ \\
\hline $\begin{array}{l}\text { Goodness-of-Fit Index } \\
\text { (GFI) }\end{array}$ & 0.901 & A good model fit \\
\hline $\begin{array}{l}\text { Root Mean Square Error } \\
\text { of Approximation } \\
\text { (RMSEA) }\end{array}$ & 0.038 & A good model fit \\
\hline \multicolumn{3}{|l|}{ Incremental Fit Indices } \\
\hline Normed Fit Index (NFI) & 0.929 & A good model fit \\
\hline $\begin{array}{l}\text { Tucker-Lewis Index } \\
\text { (TLI) }\end{array}$ & 0.932 & A good model fit \\
\hline $\begin{array}{l}\text { Comparative Fit Index } \\
\text { (CFI) }\end{array}$ & 0.935 & A good model fit \\
\hline
\end{tabular}

Source: Survey data

Except for the chi-square index, which was unacceptably high owing to a large sample size of over 6500 (Hooper, Coughlan, \& Mullen, 2008; Gatignon, 2010; Hair et al., 2010), all the other GOF indices were at a level recommended by various authors (Hair et al., 2010; Hu \& Bentler, 1999). The structural model thus provided an overall goodness of fit, despite the fact that not all research hypotheses were supported by the regression weight estimates obtained between two of the main latent variables, as will be discussed below.

\section{Discussion of the Results}

The overall mean score obtained from the survey instrument (3.21) indicated that the respondents who were part of the sample were mostly satisfied with the various aspects of the metropolitan municipality. The internal consistency scores obtained for the Effectiveness Survey ranged from a low of 0.79 to a high of 0.95 , with an overall reliability of 0.86 . These internal consistency scores support similar results obtained by Martins and Coetzee (2007), who reported reliability scores ranging from a low of 0.86 to a high of 0.92 with an overall reliability of 0.88 . 
The results of the conceptual model validity study utilising SEM confirmed two of the originally proposed hypotheses:

$\mathrm{H}_{1}$ : $\quad$ There is a significant statistical relationship between Healthy Systems (the degree of harmonious balance between various internal structural features) and Goal Achievement. This supports the views of Porter, Lawler, and Hackman (1974), Nadler and Tushman (1977), Burke and Litwin (1992), Nel and Haycock (2005) and Wiley (2010), who argue that there is a direct relationship between the smooth functioning of an organisation and goal achievement and/or results.

$\mathrm{H}_{2}$ : There is a significant statistical relationship between Healthy Systems and Service Delivery. This supports the views of Porter, Lawler, and Hackman (1974), Kaplan and Norton (1992), Nel and Haycock (2005) and Wiley (2010), who argue that there is a direct relationship between the smooth functioning of an organisation and client or customer satisfaction (service delivery).

However, SEM also indicated that two of the original hypotheses cannot be accepted:

$\mathrm{H}_{3}$ : There is a statistically significant relationship between Goal Achievement and Service Delivery; and

$\mathrm{H}_{4}$ : There is a statistically significant relationship between Service Delivery and Goal Achievement.

The insignificant statistical relationships obtained between Goal Achievement and Service Delivery and vice versa are not supported by the Baldridge National Quality Program (2007), Immordino (2010), or Wiley (2010), who all argue that there is a direct relationship between these two variables.

\section{Conclusions and Implications}

The first conclusion that can be drawn is that participants in the sample were mostly satisfied with the functioning of the metropolitan municipality that was assessed. Secondly, it can be concluded that the Effectiveness Survey is a reliable instrument for identifying developmental areas in a metropolitan municipality. Thirdly, it can be concluded that if a metropolitan municipality is functioning smoothly (there is a harmonious balance between various internal structural features), it should be able to achieve its mandated goals and deliver the required services to its inhabitants, thus ensuring customer satisfaction. Fourthly, it can be concluded that SEM is a useful statistical approach for conceptual model testing.

However, it can also be concluded that in a metropolitan municipality, goal achievement does not equate to service delivery. This suggests that although a metropolitan municipality may be achieving its mandated goals, this does not mean that it is effectively delivering services to its constituencies. This has serious implications for management, who must ensure that a metropolitan municipality's mandated goals are aligned with the needs of its constituencies, and vice versa. 


\section{Limitations and Recommendations}

Several limitations were applicable to this study. Firstly, the study was conducted in only one of the eight existing metropolitan municipalities in South Africa. For this reason, generalisation to the other seven metropolitan municipalities in South Africa requires caution. Secondly, the majority of respondents were African (82\%) and the majority had a home language other than English (90\%). As the Effectiveness Survey was developed for an English audience, respondents may not have fully understood the questions, which could have affected the validity of their answers. Although the pilot study provided valuable input into the questionnaire content, it is recommended that the proposed conceptual model in this study be validated in other metropolitan municipalities in South Africa.

It is also recommended that the Effectiveness Survey be used by practitioners and organisations to address developmental areas in metropolitan municipalities in South Africa. SEM can also be used to validate new conceptual models that will assist managers and practitioners in dealing with a variety of organisational challenges.

\section{References}

Atkinson, D. (2007). Taking to the streets: Has developmental local government failed in South Africa?” In S. Buhlungu, J. Daniel, \& R. Southall (Eds.), State of the nation: South Africa 2007 (pp. 53-77). Cape Town: Human Sciences Research Council.

Babbie, E. (2010). The practice of social research (12th ed.). Belmont: Cengage Learning.

Baldrige National Quality Program. (2007). Criteria for performance excellence 2007. Gaithersburg: National Institute of Standards and Technology, Department of Commerce.

Bartlett, M. S. (1954). A note on the multiplying factors for various chi square approximations. Journal of the Royal Statistical Society, 16(Series B), 296-298.

Baumgartner, H., \& Homburg, C. (1996). Applications of structural equation modelling in marketing and consumer research: A review. International Journal of Research in Marketing, 13(2), 139-161. doi.org/10.1016/0167-8116(95)00038-0

Beulens, M., Sinding, K., Waldstrom, C., Kreitner, R., \& Kinicki, A. (2011). Organisational behaviour (4th ed.). Berkshire: McGraw-Hill.

Boyne, G. A., \& Chen, A. A. (2006). Performance targets and public service improvement. Journal of Public Administration: Research and Theory, 17(3), 455477. doi.org/10.1093/jopart/mul007

Brown, D. R. (2011). An experiential approach to organizational development (8th ed.). New York City, NY: Pearson. 
Burke, W. W., \& Litwin, G. H. (1992). A causal model of organizational performance and change. Journal of Management, 18(3), 523-545. doi.org/10.1177/014920639201800306

Cameron, K. S. (1986). Effectiveness as paradox: Consensus and conflict in conceptions of organizational effectiveness. Management Science, 32(5), 539-553. doi.org/10.1287/mnsc.32.5.539

Cameron, K. S., \& Whetten, D. A. (1983). Organizational effectiveness: One model or several? In K. S. Cameron, \& D. A. Whetten (Eds.), Organizational effectiveness: A comparison of multiple models (pp. 1-34). New York, NY: Academic Press. doi.org/10.1016/B978-0-12157180-1.50006-9

Castro, M. L., \& Martins, N. (2010). The relationship between organisational climate and employee satisfaction in a South African information and technology organisation. SA Journal of Industrial Psychology, 36(1), 1-9. doi.org/10.4102/sajip.v36i1.800

Church, A. H., \& Waclawski, J. (1998). Designing and using organizational surveys. Brookfield, VT: Gower.

Connolly, T., Conlon, E. J., \& Deutsch, S. J. (1980). Organizational effectiveness: A multipleconstituency approach. Academy of Management Journal, 5(2), 211-217.

Creswell, J. W. (2009). Research design: Qualitative, quantitative, and mixed methods (3rd ed.). Thousand Oaks, CA: Sage.

Cummings, T. G., \& Worley, C. G. (2015). Organization development and change (10th ed.). Mason, MI: South-Western Cengage Learning.

Curry, J., \& Gay, E. (1987). Educational research: Competencies for analysis and application. Columbus, OH: Merrell.

Daft, R. L. (1992). Organization theory and design. New York, NY: West.

Fabrigar, L. R., Wegener, D. T., MacCallum, R. C., \& Strahan, E. J. (1999). Evaluating the use of exploratory factor analysis in psychological research. Psychological Methods, 4(3), 272-299. doi.org/10.1037/1082-989X.4.3.272

French, W. L., \& Bell, C. H. (1978). Organization development: Behavioral science interventions for organizational improvement (2nd ed.). Englewood Cliffs, NJ: PrenticeHall.

Gatignon, H. (2010). Statistical analysis of management data (2nd ed.). New York, NY: Springer. https://doi.org/10.1007/978-1-4419-1270-1

Gawande, K., \& Wheeler, T. (1999). Measures of effectiveness for governmental organizations. Management Science, 45(1), 42-58. 
Glunk, U., \& Wilderom, C. (1999). Organizational effectiveness = corporate performance? Why and how two research traditions need to be merged. In M. P. Cunha, \& C. A. Marques (Eds.), Readings in organization science - Organizational change in a changing context. Lisbon: ISPA. https://doi.org/10.1287/mnsc.45.1.42

Green, S. B., \& Salkind, N. (2014). Using SPSS for Windows and Macintosh: Analyzing and understanding data (6th ed.). Upper Saddle River, NJ: Prentice-Hall.

Hair, J. F., Black, W. C., Babin, B. J., \& Anderson, R. E. (2010). Multivariate data analysis (7th ed.). Englewood Cliffs, NJ: Prentice-Hall.

Harrison, M. I. (2005). Diagnosing organizations: Methods, models, and processes (3rd ed.). Thousand Oaks, CA: Sage.

Higgins, J. M. (2005). The eight "ss” of successful strategy execution. Journal of Change Management, 5(1), 3-13. doi.org/10.1080/14697010500036064

Hoe, S. L. (2008). Issues and procedures in adopting structural equation modelling technique. Journal of Applied Quantitative Methods, 3(1), 76-83.

Hooper, D., Coughlan, J., \& Mullen, M. R. (2008). Structural equation modelling: Guidelines for determining model fit. Journal of Business Research Methods, 6(1), 53-60.

Hrebiniak, L. G. (1978). Complex organizations. New York, NY: West.

Hu, L., \& Bentler, P. M. (1999). Cutoff criteria for fit indices in covariance structure analysis: Conventional criteria versus new alternatives. Structural Equation Modeling, 6(1), 155. doi.org/10.1080/10705519909540118

IBM. (2015). IBM SPSS Statistics for Windows, version 23. Armonk, NY: IBM Corp.

Immordino, K. M. (2010). Organizational assessment and improvement in the public sector. Boca Raton, FL: CRC Press.

Kaiser, H. F. (1974). An index of factorial simplicity. Psychometrica, 39(1), 31-36. doi.org/10.1007/BF02291575

Kaplan, R. S., \& Norton, D. P. (1992). The balanced scorecard-Measures that drive performance. Harvard Business Review, 70(1), 71-79.

Kline, R. B. (2011). Principles and practice of structural equation modelling (3rd ed.). New York, NY: Guilford.

Ledimo, O. M. (2012). Diagnostic model for employee satisfaction during organisational transformation. (PhD diss.). University of South Africa. 
Leibbrandt, J. H., \& Botha, C. J. (2014). Leadership and management as an enabler for strategy execution in municipalities in South Africa. Mediterranean Journal of Social Sciences, 5(20), 329-339. doi.org/10.5901/mjss.2014.v5n20p329

Likert, R. (1932). A technique for the measurement of attitudes. Archives de Psychologie, 22(140), 1-55.

Martinez-Pons, M. (1997). Research in the social sciences and education: Principles and process. Lanham, MD: University Press of America.

Martins, N., \& Coetzee, M. (2007). Organisational culture, employee satisfaction, perceived leader emotional competency and personality type: An exploratory study in a South African engineering company. SA Journal of Human Resource Management, 5(2), 20-32. doi.org/10.4102/sajhrm.v5i2.116

Martins, N., \& Geldenhuys, D. (2016). Fundamentals of organisational development. Cape Town: Juta.

Martz, W. A. (2008). Evaluating organizational effectiveness. (PhD diss.). Western Michigan University, Kalamazoo.

Nadler, D. A., \& Tushman, M. L. (1977). A diagnostic model for organization behavior. In J. R. Hackman, \& L. W. Porter (Eds.), Perspectives on behaviour in organizations. New York, NY: McGraw-Hill.

Nel, W., \& Haycock, E. (2005). Service excellence: Customer satisfaction measurement in local government green industries. Journal of Public Administration, 40(1), 247-268.

Parhizgari, A. M., \& Gilbert, G. R. (2004). Measures of organizational effectiveness: Private and public sector performance. Omega, 32(3), 221-229.

doi.org/10.1016/j.omega.2003.11.002

Patterson, M. G., West, M. A., Shackleton, V. J., Dawson, J. F., Lawthom, R., Maitlis, S., ... \& Wallace, A. M. (2005). Validating the organizational climate measure: Links to managerial practices, productivity and innovation. Journal of Organizational Behavior, 26(4), 379408. doi.org/10.1002/job.312

Peng, C. Y. J., Harwell, M., Liou, S. M., \& Ehman, L. H. (2006). Advances in missing data methods and implications for educational research. In S. Sawilowsky (Ed.), Real data analysis (pp. 31-78). Greenwich: Information Age.

Poister, T. H., \& Streib, G. D. (1999). Performance measurement in municipal government: Assessing the state of the practice. Public Administration Review, 59(4), 325335. doi.org/10.2307/3110115

Porter, L. W., Lawler, E. E., \& Hackman, J. R. (1974). Behavior in organisations. Tosko: Japan Printing. 
Price, J. L. (1972). The study of organizational effectiveness. Sociological Quarterly, 13(1), 35. https://doi.org/10.1111/j.1533-8525.1972.tb02100.x

Reddy, P. S. (2008). Metropoles in Africa. In P. S. Reddy, M. S. Haque, \& M. S. de Vries (Eds.), Improving local government: outcomes of comparative research (pp. 45-71). New York, NY: Palgrave Macmillan. doi.org/10.1057/9780230287310_4

Rojas, R. R. (2000). A review of models for measuring organizational effectiveness among forprofit and nonprofit organizations. Nonprofit Management and Leadership, 11(1), 97-104.

Roth, P. L. (1994). Missing data: A conceptual review for applied psychologists. Personnel Psychology, 47(3), 537-559. doi.org/10.1111/j.1744-6570.1994.tb01736.x

Ruscio, J., \& Roche, B. (2012). Determining the number of factors to retain in an exploratory factor analysis using comparison data of known factorial structure. Psychological Assessment, 24(2), 282-292. doi.org/10.1037/a0025697

Soni, V. (2011). A general framework for understanding the 21st century public sector organizations. International Journal of Public Administration, 34(1), 76-83. doi.org/10.1080/01900692.2011.536083

Statistics South Africa. (2013). Mid-year population estimates. Statistical release P0302. Pretoria: Stats SA.

Steers, R. M. (1977). Organizational effectiveness: A behavioural view. Santa Monica, CA: Goodyear.

Stevens, P. A. (2005). Assessing the performance of local government. National Institute Economic Review, 193(1), 90-101. doi.org/10.1177/0027950105058565

Thorndike, R. L. (1949). Personnel selection: Test and measurement techniques. New York, NY: Wiley.

Thurstone, L. L. (1947). Multiple factor analysis. Chicago, IL: University of Chicago Press.

Tichy, N. M. (1983). Managing strategic change: Technical, political, and cultural dynamics. New York, NY: Wiley.

Tsui, A. S. (1984). A role set analysis of managerial reputation. Organizational Behavior and Human Performance, 34(1), 64-96. doi.org/10.1016/0030-5073(84)90037-0

Van Thiel, S., \& Leeuw, F. L. (2002). The performance paradox in the public sector. Public Performance and Management Review, 25(3), 267-281.

doi:10.1080/15309576.2002.11643661 
Vaughan, S. K. (2010). The importance of performance assessment in local government decisions to fund health and human services nonprofit organizations. Journal of Health and Human Services Administration, 32(4), 486-512.

Waheed, A., Mansor, N., \& Ismail, N. A. (2010). Assessing performance of public sector organizations: A theoretical framework. Interdisciplinary Journal of Contemporary Research in Business, 2(8), 329-349.

Waterman, R. H., Jr., Peters, T. J., \& Phillips, J. R. (1980). Structure is not organization. Business Horizons, 23(3), 14-26. doi.org/10.1016/0007-6813(80)90027-0

Weisbord, M. R. (1976). Organizational diagnosis: Six places to look for trouble with or without a theory. Group and Organization Studies, 1(4), 430-447. doi.org/10.1177/105960117600100405

Wiley, J. W. (2010). Strategic employee surveys. San Francisco, CA: Jossey-Bass.

Yuchtman, E., \& Seashore, S. E. (1967). A system resource approach to organizational effectiveness. American Psychological Review, 32(6), 891-903. doi.org/10.2307/2092843 